Section Editor

Mitchell S.V. Elkind,

MD, MS

Roberto Erro, MD

Sabina Pappatà, $\mathrm{PhD}$

Marina Picillo, MD

Mariangela Rocco, MD

Gabriella Santangelo,

$\mathrm{PhD}$

Paolo Barone, MD, PhD

Carmine Vitale, MD,

$\mathrm{PhD}$

Correspondence to

Dr. Vitale:

cavit69@hotmail.com

\title{
Teaching NeuroImages: \\ Pseudo-abnormal DaTscan findings in meningioma-induced parkinsonism
}
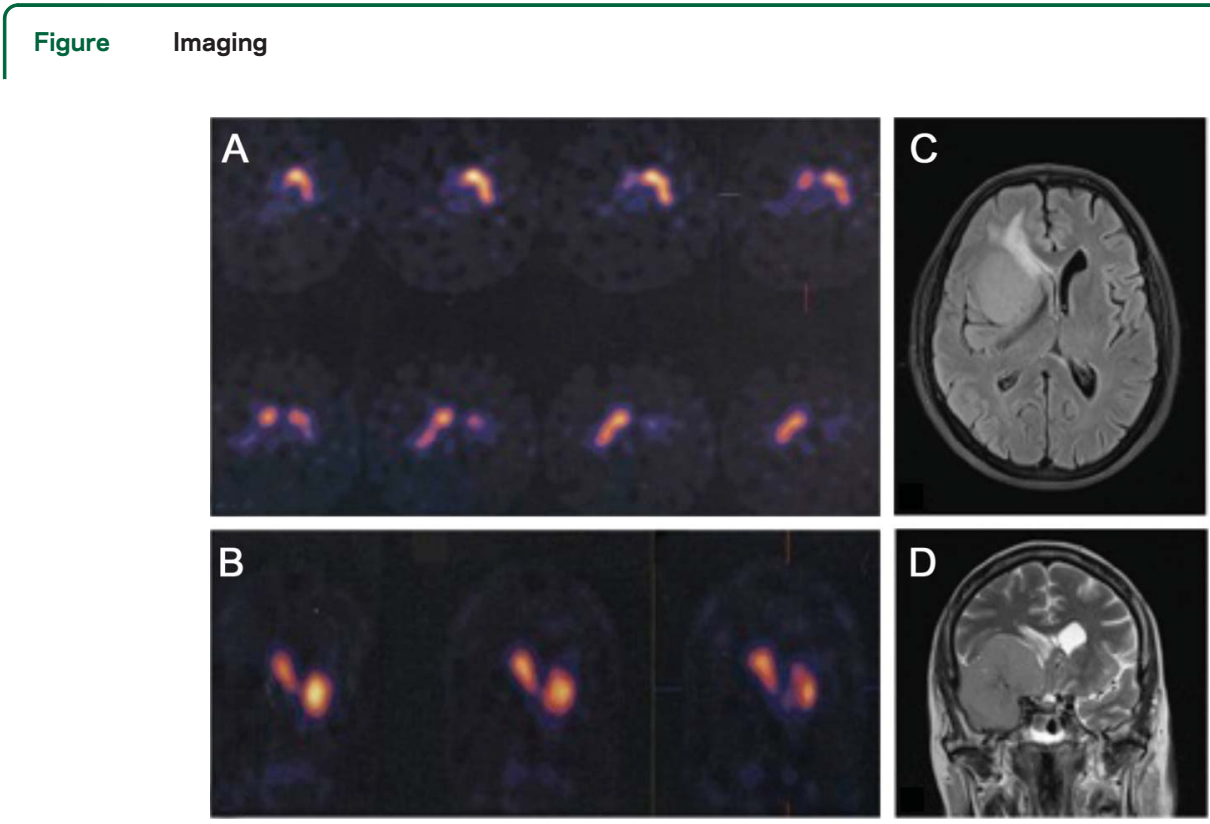

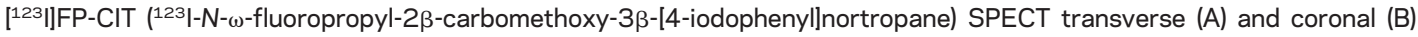
slices showing dislocation of the right striatum upward and medially. MRI transverse T1 (C) and coronal T2 (D) sequences revealing a right frontal meningioma with mild surrounding edema.

A 71-year-old man presented with a 6-month history of rest tremor and slowness in his left hand. Apart from mild left parkinsonism, neurologic examination was unremarkable. Because response to L-dopa, up to $600 \mathrm{mg} / \mathrm{d}$,

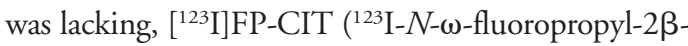
carbomethoxy-3 $\beta$-[4-iodophenyl]nortropane) SPECT was prescribed with unexpected results: transverse and coronal slices showed the right striatum to be moved upward and medially, suggesting a structural compression rather than degenerative damage (figure). Brain MRI revealed the presence of a frontal meningioma. Caution is required when interpreting DaTscan findings, ${ }^{1,2}$ and morphologic imaging should always be performed first.

\section{AUTHOR CONTRIBUTIONS}

Dr. R. Erro: acquisition of data, analysis and interpretation, writing the first draft. Dr. S. Pappatà: acquisition of data, analysis and interpretation, critical revision of the manuscript for important intellectual content. Dr. M. Picillo, Dr. M. Rocco, and Dr. G. Santangelo: acquisition of data. Prof. P. Barone: interpretation of data, critical revision of the manuscript for important intellectual content. Dr. C. Vitale: analysis and interpretation of data, critical revision of the manuscript for important intellectual content.

\section{STUDY FUNDING}

No targeted funding reported.

\section{DISCLOSURE}

The authors report no disclosures relevant to the manuscript. Go to Neurology.org for full disclosures.

\section{REFERENCES}

1. Perlmutter JS, Eidelberg D. To scan or not to scan: $\mathrm{DaT}$ is the question. Neurology 2012;78:688-689.

2. Biancheri-Mounicq I, Colombié M, Pin JC, Lecoanet A, Adam-Tariel F. Unexpected finding on I-123 FP-CIT SPECT leading to the diagnosis of cerebral meningioma. Clin Nucl Med 2011;36:156-157.

From the University of Naples (R.E., M.P., M.R.), Federico II, Naples; Institute of Biostructure and Bioimaging (S.P.), CNR, Naples; Istituto di Diagnosi e Cura Hermitage Capodimonte (G.S., P.B., C.V.), Naples; Department of Psychology (G.S.), Second University of Naples, Caserta; University of Salerno (P.B.), Center for Neurodegenerative Diseases, Salerno; and University Parthenope (C.V.), Naples, Italy. 


\section{Neurology}

\section{Teaching NeuroImages: Pseudo-abnormal DaTscan findings in meningioma-induced parkinsonism}

Roberto Erro, Sabina Pappatà, Marina Picillo, et al. Neurology 2013;80;e147

DOI 10.1212/WNL.0b013e318289709d

\section{This information is current as of March 25, 2013}

\section{Updated Information \&} Services

References

Subspecialty Collections

Permissions \& Licensing

Reprints including high resolution figures, can be found at: http://n.neurology.org/content/80/13/e147.full

This article cites 2 articles, 1 of which you can access for free at: http://n.neurology.org/content/80/13/e147.full\#ref-list-1

This article, along with others on similar topics, appears in the following collection(s):

MRI

http://n.neurology.org/cgi/collection/mri

Parkinson's disease/Parkinsonism

http://n.neurology.org/cgi/collection/parkinsons_disease_parkinsonism Primary brain tumor

http://n.neurology.org/cgi/collection/primary_brain_tumor SPECT

http://n.neurology.org/cgi/collection/spect

Information about reproducing this article in parts (figures,tables) or in its entirety can be found online at:

http://www.neurology.org/about/about_the_journal\#permissions

Information about ordering reprints can be found online:

http://n.neurology.org/subscribers/advertise

Neurology ${ }^{\circledR}$ is the official journal of the American Academy of Neurology. Published continuously since 1951 , it is now a weekly with 48 issues per year. Copyright @ 2013 American Academy of Neurology. All rights reserved. Print ISSN: 0028-3878. Online ISSN: 1526-632X.

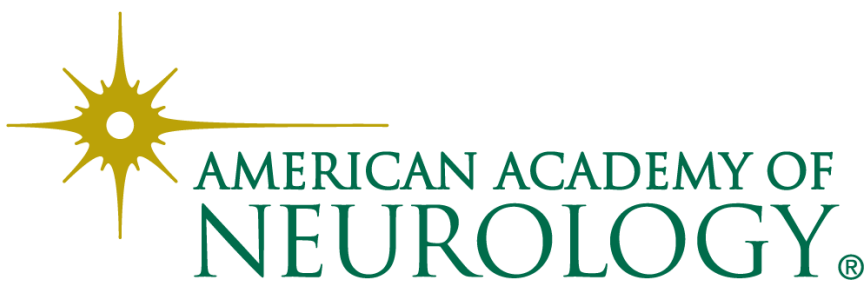

